\title{
Configurações
}

Revista Ciências Sociais

26 | 2020

Economy and Society: politics, practices, agents, and institutions

\section{Introduction to the Thematic Dossier | Economy and Society: politics, practices, agents, and institutions}

Rodrigo da Costa Dominguez, Lisbeth Rodrigues, Jeremy Land e Jari Eloranta

\section{OpenEdition}

\section{Edição electrónica}

URL: http://journals.openedition.org/configuracoes/10367

DOI: 10.4000/configuracoes. 10367

ISSN: $2182-7419$

\section{Editora}

Centro de Investigação em Ciências Sociais

Edição impressa

Paginação: 7-17

ISSN: 1646-5075

\section{Refêrencia eletrónica}

Rodrigo da Costa Dominguez, Lisbeth Rodrigues, Jeremy Land e Jari Eloranta, «Introduction to the Thematic Dossier | Economy and Society: politics, practices, agents, and institutions », Configurações [Online], 26 | 2020, posto online no dia 16 dezembro 2020, consultado o 18 dezembro 2020. URL: http://journals.openedition.org/configuracoes/10367; DOI : https://doi.org/10.4000/configuracoes. 10367 
Dominguez, Rodrigo da Costa; Rodrigues, Lisbeth; Land, Jeremy; Eloranta, Jari - Introduction to the Thematic Dossier: Economy and Society: politics, practices, agents, and institutions. Configurações, vol. 26, 2020, pp. 7-17.

\title{
Introduction to the Thematic Dossier | Economy and Society: politics, practices, agents, and institutions
}

\author{
RODRIGO DA COSTA DOMINGUEZ* \\ CICS - University of Minho \\ LISBETH RODRIGUES** \\ CSG-ISEG - University of Lisbon \\ JEREMY LAND*** \\ University of Jyväskylä and University of Helsinki \\ JARI ELORANTA**** \\ University of Helsínki
}

\section{Interplay of the Economy and Society}

The economic orientation or the concept of "economic action" (Wirtschaften) introduced by Max Weber in his essays on the sociology of economics addresses the issue of satisfying desires for "utilities" (Nutzleistungen) as an exercise of an actor's control over a certain resource. This resource is, originally, driven and directed towards economic ends. Following this common thread, "... the definition of 'economic action' must be further manifested in such a way as to include the operation of a modern business enterprise run for profit", and all economic processes and objects are characterized by the meaning they have for human action in playing such roles as ends, means, obstacles, and by-products (Weber, 1978; see also, Ringer, 2002).

In this context, the basic concepts that economics and economic history use to analyze the society, such as the ideas pertaining to growth, prosperity, development and globalization, and/or expansion/interconnection are essentially modern, distinguished by the transformation from the $14^{\text {th }}$ to the $16^{\text {th }}$ centuries, but also and above all, as some scholars have indicated, "... with a new design of economic frontiers [...], beginning with demographic growth and the recomposition and greater diversification of productive tissues" (Costa, Lains and Miranda, 2011: 14). In fact,

\footnotetext{
*E-mail: rcdominguez@ics.uminho.pt

**E-mail: Irodrigues@iseg.ulisboa.pt

***E-mail: land25.jeremy@gmail.com

****E-mail: jari.eloranta@helsinki.fi
} 
we would argue that economic history, understood broadly, can serve as a conduit for interdisciplinary understanding of various topics, problems, and time periods, regardless of the methodology used. However, this type of broad debate is often limited to specific topics that transcend disciplinary boundaries, such as slavery, war, economic activity, and inequality (Szostak, 2006; Eloranta et al., 2010; Lamoreax, 2015; Wright and Ville, 2017). And certain topics, like the discussion of the impacts and origins of capitalism can get fairly heated, and the methodological boundaries can be hard to overcome (Galambos, 2014; Hilt, 2017; Olmstead and Rhode, 2018; Beckert and Desan, 2018). One broader area where economic, business, and social history have been able to interact with methodological freedom has been the so-called social science history, which has become a big theoretical and empirical arena for many. Many of the conferences linked to social science history have grown very large in the 2010s (Bearman et al., 1999; Komlos and Baten, 2004; Inwood and Stewart, 2020). Our approach is to embody the methodological and topical openness of social science history.

In this volume, we are trying to think about the interplay of the economy and the society as an organism with organizations and agents interacting in an evolving institutional framework over time (North, 2016; Greif and Mokyr, 2017). Thus, this volume aims to approach these issues in an (inter) multidisciplinary way and bring together studies that create interdisciplinary pathways between economic history, sociology, and economics, following the theoretical ideas already set up by Weber and many other scholars since. This is also the path taken by many economic historians in recent years, both with its themes as well as its present and future challenges, and the views of the place of social sciences within the perspective of Western capitalist development (see, e.g., Mokyr, 2002; Clark, 2008; McCloskey, 2010; Piketty, 2014). What they have in common is the idea that the substantial scientific-technological advances and the progress of the medical and other fields of sciences served as building blocks of development, via political action that resulted in the construction of public policies of investment in science, knowledge, and technology. Without losing sight of the current issues, such as the West-East trade wars and global competition, the agenda of sustainable development and preservation of natural resources, the applied social sciences (economics), as well as the humanities (sociology and history, especially economic history), are fundamental in the perception of the various and different contexts related to the states' actions and economic agendas (Frank and Gills, 1993; Oosthoek and Gills, 2005; Borowy and Schmelzer, 2017). In addition, they also play a fundamental role in understanding the proposals, whether radical or moderate, to foster development and to protect domestic economic institutions and dynamics, both nationally and regionally, within their respective trade blocs and agreements that unite them. These themes unite the study of economies and societies in the long run, using a broad variety of methods, and they will guide the future studies of economic history, broadly understood. 
In this issue, our goal was to assemble a set of articles that contribute in an original way to the scientific debate on economics, economic history, and social sciences, based on multiple interdisciplinary, theoretical, methodological, and empirical approaches, which will provide the reader, through innovative and enriching visions, the improvement of their understanding in those topics, in particular on the following themes, especially from the modern era onwards. Some of the themes that emerged in the set of articles that made it to the final volume include trade as a historical and sociological phenomenon; economic development over time in various sectors of the economy and time periods; public and private financing of economic activity; organization of societal systems and how they interact with the institutional frameworks over time; social and economic dimensions of markets and how various agents interacted in them. In that sense, while the articles do not form a uniform whole like an edited volume, there are some common themes that correspond to the goals we initially laid out.

While the methodologies of each article vary greatly, all the articles utilize specific micro and macro data sources, such as merchant account books, newspapers, bills of lading, ship logbooks, and various governmental records. Using these sources, this issue seeks to explore specific case studies and sectors of trade to tell a broader story of the intricate nature and fragility of the global economy, past and present. For example, Eric Oakley shows how sandalwood as a source of trade was quite profitable for American merchants as a means to gain access to Chinese ports and goods, but just a few years after the trade was well established it collapsed. This fragility is a key, yet invisible theme throughout this issue where local conditions and the global economy interact in a constant, if not always visible, dance. No matter how isolated a region might seem, global forces influence that locale's economic activity, and local actors can and continue to influence the global flows of commodities and capital.

This issue also engages directly and indirectly with the arguments laid out by Daren Acemoglu and James Robinson in their seminal volume, Why Nations Fail (2012), and their latest book (reviewed in this issue, in fact), The Narrow Corridor (2019). In essence, Acemoglu and Robinson argue that nations (read: institutions) that foster political and economic inclusiveness tend to succeed, whereas nations who fail to do so tend to fail. With any broad argument, detailed case studies and examples frequently complicate the overall argument. Nevertheless, the general rule seems to hold in the long-run, and some of the articles included in this issue, i.e., the Eloranta and Widener discussion of radio and politics in Argentina, highlight the perils of concentrating both political and economic power in the hands of a few, as well as the institutional dynamics of growing populism.

A weakness in the Acemoglu/Robinson hypotheses is how one measures the effectiveness of institutions. Should we rely solely on military capacity? Or should we consider revenue collection as the primary signal of efficacy? It is in no small part 
due to the questions raised by Acemoglu and Robinson that the last decade has witnessed a major increase in the number of articles, books, and well-funded research projects looking at institutional capacity as a primary focus of economic and social history (Dincecco, 2017; Eloranta, et al.,2019; Henriques and Palma, 2020). No doubt, the central thesis that institutions matter is true, but to what extent they matter and how greatly depends on the research questions asked of the sources and societal contexts. As many reviewers have noted, Acemoglu and Robinson gloss over the contingencies of history, and more often than not remove the individual from the collective narrative. The articles in this issue seek to fill these glaring voids in the otherwise instructive model by examining several case studies in the late early modern and modern periods.

This economic, business, and social history has also echoed strongly in Portugal over the last several decades. After the Carnation Revolution of 1974, a new agenda for economic and social history began, mainly stimulated by scholars like Vitorino Magalhães Godinho, Joaquim Romero Magalhães, Nuno Valério, and Jaime Reis. The creation of the Portuguese Association of Economic and Social History (APHES) in the early 1980 s is symptomatic of this transition. A new political reality ensured by freedom of speech convinced many students to engage in courses in the human and social sciences, creating a new academic context characterized by a great student demand.

The growth of fields and topics that connect economy, social practices, institutions, and policies is well known. Great collective works were created, giving more space to the economic and social aspects of Portugal's history, such as A. H. de Oliveira Marques' Nova História de Portugal (1987-2004), José Mattoso's História de Portugal (1993), Pedro Lains and Álvaro Ferreira da Silva's História Económica de Portugal, c. 1700-2000 (vols. 3, 2005), and Leonor Freire Costa, Pedro Lains and Susana Münch Miranda's An Economic History Portugal, c. 1143-2010 (2016). Other fundamental works have appeared in various fields of Portuguese economic history, such as the areas of financial, banking, and economic policies (Reis, 1993, 1996; Esteves, 2002; Valério, 2007, 2010; Amaral, 2019; Lains, 2021), institutions and institutional development (Hespanha, 2004; Reis, 2011), and the decisive role that those institutions played in the growth of modern Portuguese economy.

These developments led to a substantial increase in scholarship on the economic history of Portugal on a wide range of themes, such as agriculture, fishery, and wine business (Garrido, 2006; Pereira, 2010; Freire and Lains, 2017), migrations, demography and its impact on labor markets (Amorim, 1992; Alves, 1994), industry, and industrial heritage (Macedo, 1982; Pedreira, 1994; Madureira, 1997; Cordeiro, 2017), colonial trade and commodities (Pedreira, 2000; Costa, 2002), slavery and slave trade (Capela, 2002; Richardson and Silva, 2015), empires and networks (Antunes, 2009; Antunes and Polónia, 2016). These works were fundamental in composing a more comprehensive view of Portugal's economic history, combining quantitative 
research techniques with traditional sources and new datasets, "revealing the strength of studies in which there is a concern for the interaction of economic history with other disciplines of knowledge" (Magalhães, 2012).

Two main features can be discerned from the recent studies of Portuguese economic history. First, scholars have taken a long-term perspective to search for the causes of Portuguese economic performance. Second, datasets from primary sources have been comprehensively and systematically assembled, many using a comparative approach. Both methodologies have many benefits, but possibly the most apparent of them is bringing the Portuguese case into the greater European debate, from which it had been absent until recently. In fact, Portuguese economic literature has been in dialogue with their European counterparts, and Portugal is slowly gaining greater attention in the field of global economic history, which is appropriate for a society that has had a substantial impact on the global history, especially via its extensive empire.

Although Portugal's economic backwardness has been studied extensively in the past Portuguese historiography, it has also been frequently revisited and is currently one of the most promising topics. In 2019, Palma and Reis presented the first GDP series from 1527 to 1850 , showing that Portugal's economy began to decline from the mid-eighteenth century onwards. Different topics have been considered to explain the national long-run economic performance. The efficiency of the judicial system (Reis, 2010, 2011), the relevance of the empire (Costa, Palma and Reis, 2015), the private and public interest rates (Costa, Rocha and Brito, 2018), the female participation in the labor market (Silva and Carvalhal, 2020), or the political institutions' quality (Henriques and Palma, 2020) are some of the hot topics. It is also worth mentioning that all these studies take a comparative approach. For instance, the studies of Henriques and Palma (2020) and of Silva and Carvalhal (2020) have shed some light on Portugal's position in the broader debate of the "Little Divergence". They showed that Iberian political institutions were no worse than in England or the Netherlands and that women participated less in the labor market compared to Northwestern Europe. Both the long-run perspective and the comparative approaches that the recent literature has been pursuing are slowly and steadily allowing the Portuguese case to be considered in the broader economic history literature agenda.

\section{Main Contributions of the Thematic Dossier}

The first three articles here deal with the late early modern period roughly between 1750-1850. Tomás de Albuquerque's article focuses on the resurgence of Portuguese trade in Asia in the last quarter of the 18th century. Drawing on the ledgers produced by two expeditions, "Trovoada Pequeno" and "Trovoada Grande", the author 
discusses both the financing of the Portuguese commercial expeditions to Asia and the products involved in these initiatives. The two case studies reveal that the Portuguese Asian maritime trade relied strongly on Lisbon-based capital rather than foreign capital. Albuquerque shows that the capital collected in the metropolis was converted into European commodities which were sold in India, where the Portuguese acquired silver and the credit they needed to trade in China. Moreover, the resurgence of the Portuguese interest in Asia was mainly driven by the business of tea and other Chinese commodities.

Focusing on the role and responses of the oft-ignored indentured servants in Virginia on the eve of the American Revolution, Antonio Bly and Ryan Ingerick offer a new approach to understanding why how indentured servants were caught in the middle between an empire on the one hand and their masters on the other in the 1770s before the Declaration of Independence was signed. Indentured servants in colonial America have been overlooked in the past by historians seeking to understand the role of coerced labor in the origins of the United States. Bly and Ingerick seek to clarify the contemporary view of indentured servants, without allowing the concurrent and subsequent focus on African slavery to overcome the large and active population of indentured servants in the Virginian economy. Focusing their study on the royal Virginian governor's declaration inviting indentured servants to join the war effort to help quell the growing rebellion, the authors reconsider the place of indentured servants within a revolutionary society.

In his article on the sandalwood trade, Eric Oakley engages in a multi-layered approach to understanding the mechanisms and importance of the arrival of Americans in the Pacific and Indian Ocean economies. Newly independent from Britain, American merchants immediately sought to establish a profitable trade with China via the Pacific Ocean. In these efforts, they looked to find the right commodities which they could trade with Chinese merchants for tea, porcelain, and other East Asian goods. Sandalwood offered a key alternative to fur, the initial engine of trade for Americans in East Asia. Oakley shows how sandalwood provided American merchants the time and profits necessary to navigate away from fur as a basis for American economic action in the Pacific Ocean to other, more resilient commodities. His article on the sandalwood trade is the first specialized exploration of the commodity in more than fifty years, and the first to fully explore the American role in the trade.

The final three articles cover the last couple of decades of the 19th century and to roughly 1950. Carlos Faísca's article on the economy and ecology in the Iberian Cork Oak forests discusses the supply of raw material and how it impacted the cork industries in Spain and Portugal, mainly in the 19th century. Here we have an interdisciplinary discussion of the sustainability of industrialization and trade, and the author analyzes for example the impacts of these processes on the soil. The author argues that there were significant impediments to the development of this sector 
in the Iberian Peninsula. Moreover, the soil mobilization and extractive practices led to a decline in soil fertility, which in turn had negative economic and environmental legacies. Faísca's contribution continues a recent, but important, trend in blending economic and business history research with an eye on the ecological and environmental impacts of economic activity, past and present.

In his article, Leonardo Aboim Pires examines the state intervention in the rice sector in twentieth-century Portugal. The article explores the 1930 s economic context, identified as a critical period for the Portuguese economy. Pires seeks to ascertain the role of the rice sector's socio-economic forces and explain how corporatism helped to solve the sector's production, industrial process, and commercialization issues. Based on a thorough analysis of a diverse set of primary sources, he argues that corporatism's institutionalization was the solution found to carry out the necessary readjustments to the rice sector's economic performance. The pressure and consternation of both the oligarchy and the rice sector's industrialists and traders culminated in a more significant state interference, shifting from a free trade model to state participation. During the 1930s, due to the policies adopted, rice imports declined and, consequently, an increase in its production. However, the state also meddled in the latter by restricting rice growing and reducing cultivation areas.

Jari Eloranta and Nathan Widener explore the rise of Juan Perón as a political power in Argentina and the elections of 1946 and 1948. Eloranta and Widener argue that once in power Perón consolidated his political control by gaining ownership over the radio waves of 1940s Argentina. By necessity, the article utilizes both qualitative and quantitative methodologies to analyze how radio influenced the two elections. The interplay of institutions, technology, and economy are at the center of this new interpretation of Argentina under the Perón regime, highlighting how the rise of populism can be linked to clever uses of media.

This issue also includes two long-form book reviews which highlight two important contributions to the field. The choice relied in two recent volumes that provides relevant inputs to the debate highlighted by this thematic dossier, namely how institutions play an important role to define and guide states' economic policies and what kind of dynamics a revolution can bring to change institutional paradigms, especially regarding secular economic practices. Henri Aaltonen and Jari Eloranta discuss in detail the newest book from Daron Acemoglu and James Robinson entitled The Narrow Corridor: States, Societies, and the Fate of Liberty, a follow up to their groundbreaking Why Nations Fail. The review addresses how the book fits within the larger argument and hypotheses that Acemoglu and Robinson propose in previous works and makes note of areas wherein further research is both warranted and necessary.

Paulo Jorge Fernandes reviews, in detail, the recent book from José Manuel Lopes Cordeiro 1820. Revolução Liberal do Porto (2020), published within the commemoration of the 200th anniversary of the Liberal Revolution in Portugal. 
Through his sharp lens, Fernandes guides us through nine different book chapters, beginning with the revolution's background, moving then to the revolution itself, and culminating with the reception of the revolution in Brazil, which resulted in King João VI's return to Portugal. The book and its review, which broadly cover all political, social, and economic spheres, will undoubtedly be of interest to the readers of this dossier.

The COVID-19 pandemic, as a historical moment, is also approached in this issue. Vincent Geloso's interview offers some insights on the economic impacts of an unexpected global health issue. From a comparative perspective with previous similar events in the history of mankind (and underlining what is the best approach to make such comparisons), Geloso discusses the benefits and perils of liberal democratic institutions and how democracies tend to handle better pandemics in the long-run, based on his recent research examining the impact that pandemics can cause to states and their economies.

Overall, this thematic dossier aims to offer the readers, above all, (inter) multidisciplinary approaches to the issues addressed in these papers, book reviews, and interview. Moreover, it is intended to bring together studies that create interdisciplinary synergy between economic history, sociology, and economics, following many of the theories previously discussed in this short introduction. The editors of this dossier are pleased to offer this volume which reflects an interdisciplinary and knowledge-building dynamic supported by cooperation and teamwork between scholars from the various areas of the social sciences.

\section{Bibliography}

ACEMOGLU, Daron, ROBINSON James (2019), The Narrow Corridor: States, Societies, and the Fate of Liberty, New York, Penguin Press.

ACEMOGLU, Daron, ROBINSON, James (2012), Why Nations Fail: The Origins of Power, Prosperity and Poverty, New York, Crown Publishers.

ALVES, Jorge Fernandes (1994), Os brasileiros: emigração e retorno no Porto oitocentista, Porto, author's edition.

AMARAL, Luciano (2019), The Modern Portuguese Economy in the Twentieth and Twenty-First Centuries, Palgrave Macmillan.

AMORIM, Maria Norberta (1992), Evolução demográfica de três paróquias do sul do Pico, 16801980, Braga, Instituto de Ciências Sociais da Universidade do Minho.

ANTUNES, Cátia (2009), Lisboa e Amsterdão: Um caso de Globalização na História Moderna, Lisboa, Livros Horizonte.

ANTUNES, Cátia, POLÓNIA, Amélia (2016), Beyond Empires: Global, Self-Organizing, CrossImperial Networks, 1500-1800, Leiden, Boston, Brill.

BEARMAN, Peter, FARIS, Robert, MOODY, James (1999). "Blocking the Future: New Solutions for Old Problems in Historical Social Science", Social Science History, 23(4), 501-533.

BECKERT, Sven, DESAN, Christine (eds.) (2018), American Capitalism: New Histories, New York, Columbia University Press. 
BOROWY, Iris, SCHMELZER, Matthias (eds.) (2017), History of the Future of Economic Growth: Historical Roots of Current Debates on Sustainable Degrowth, London, New York, Routledge. CAPELA, José (2002), O tráfico de escravos nos portos de Moçambique, c. 1717-1904, Porto, Afrontamento.

CLARK, Gregory (2008), A Farewell to Alms: A Brief Economic History of the World, Princeton, Oxford, Princeton University Press.

CORDEIRO, José Manuel Lopes (2017), História da indústria portuense, Vol. I - Dos finais do século XVIII a 1852, Porto, Afrontamento.

COSTA, Leonor Freire (2002), O transporte no Atlântico e a Companhia Geral de Comércio do Brasil (1580-1663), 2 vols. Lisboa, CNCDP.

COSTA, Leonor Freire, PALMA, Nuno, REIS, Jaime (2015), "The Great Escape? The Contribution of the Empire to Portugal's Economic Growth, 1500-1800", European Review of Economic History, 19(1), 1-22.

COSTA, Leonor Freire, ROCHA, Maria Manuela, BRITO, Paulo B. (2018), "The Alchemy of Gold: Interest Rates, Money Stock, and Credit in Eighteenth-Century Lisbon", The Economic History Review, 71(4), 1147-1172.

DINCECCO, Mark (2017), State Capacity and Economic Development: Present and Past, Cambridge, Cambridge University Press.

ELORANTA Jari, GOLSON, Eric, HEDBURG, Peter, MOREIRA, Maria Cristina (eds.) (2019), Small and Medium Powers in Global History: Trade, Conflicts, and Neutrality from the $18^{\text {th }}$ to $20^{\text {th }}$ Centuries, New York, Routledge.

ELORANTA, Jari, OJALA, Jari, VALTONEN, Heli (2010), "Quantitative Methods in Business History: An Impossible Equation?", Management \& Organizational History, 5(1), 79-107.

ESTEVES, Rui Pedro (2002), Finanças públicas e crescimento económico. O crowding out em Portugal da Regeneração ao final da Monarquia, Lisboa, Banco de Portugal.

FRANK, Andre Gunder, GILLS, Barry K. (eds.) (1993), The World System: Five Hundred Years or Five Thousand?, London, New York, Routledge.

FREIRE, Dulce, LAINS, Pedro (eds.) (2017), An Agrarian History of Portugal, 1000-2000, Leiden, Boston, Brill.

GALAMBOS, Louis (2014), "Is this a Decisive Moment for the History of Business, Economic History, and the History of Capitalism?", Essays in Economic \& Business History, 32(1), 1-18.

GARRIDO, Álvaro (2006), Economia e política das pescas portuguesas. Ciência, direito e diplomacia nas pescarias do bacalhau (1945-1974), Lisboa, Imprensa de Ciências Sociais.

GREIF, Avner, MOKYR, Joel (2017), "Cognitive Rules, Institutions, and Economic Growth: Douglass North and Beyond", Journal of Institutional Economics, 13(1), 25-52.

HENRIQUES, António Castro, PALMA, Nuno (2020), "Comparative European Institutions and the Little Divergence, 1385-1800", CGEH Working Paper Series, Working paper no. 84.

HESPANHA, António Manuel (2004), Guiando a mão invisível. Direito, Estado e lei no liberalismo monárquico português, Coimbra, Almedina.

HILT, Eric (2017), "Economic History, Historical Analysis, and the "New History of Capitalism", The Journal of Economic History, 77(2), 511-536.

INWOOD, Kris, MAXWELL-STEWART, Hamish (2020), "Selection Bias and Social Science History", Social Science History, 44(3), 411-416.

KOMLOS, John, BATEN, Jörg (2004), “Looking Backward and Looking Forward: Anthropometric Research and the Development of Social Science History", Social Science History, 28(2), 191-210.

LAINS, Pedro (forth. 2021), A History of Public Banking in Portugal in the 19th and 20th Centuries. The Caixa Geral de Depósitos, London, New York, Routledge.

LAMOREAUX, Naomi (2015), "The Future of Economic History Must Be Interdisciplinary", The Journal of Economic History, 75(4), 1251-1257. 
MACEDO, Jorge Borges de (1982), Problemas da História da Indústria Portuguesa no Século XVIII, Lisboa, Querco.

MADUREIRA, Nuno Luís (1997), Mercado e privilégios. A indústria portuguesa entre 1750-1834, Lisboa, Estampa.

MAGALHÃES, Joaquim Romero (2012), "Breve panorama da história económica em Portugal, 18602004" in No Portugal Moderno: Espaços, Tratos e Dinheiros - Miúnças 3, Coimbra, Coimbra University Press, 325-354.

MCCLOSKEY, Deirdre N. (2010), The Bourgeois Virtues: Ethics for an Age of Commerce, Chicago, University of Chicago Press.

MOKYR, Joel (2002), The Gifts of Athena: Historical Origins of the Knowledge Economy, Princeton, New Jersey, Princeton University Press.

NORTH, Douglass C. (2016), "Institutions and Economic Theory", The American Economist, 61(1), 72-76.

OLMSTEAD, Alan L., RHODE, Paul W. (2018), "Cotton, Slavery, and the New History of Capitalism", Explorations in Economic History, 67, 1-17.

OOSTHOEK, Jan, GILLS, Barry K. (2005), “Humanity at the Crossroads: The Globalization of Environmental Crisis", G lobalizations, 2(3), 283-291.

PALMA, Nuno, REIS, Jaime (2019), "From Convergence to Divergence: Portuguese Economic Growth, 1527-1850", The Journal of Economic History, 79(2), 477-506.

PEDREIRA, Jorge (1994), Estrutura industrial e mercado colonial. Portugal e Brasil (1780-1830), Lisboa, Difel.

PEDREIRA, Jorge (2000), "From Growth to Collapse: Portugal, Brazil, and the Breakdown of the Old Colonial System", Hispanic American Historical Review, 80(4), 839-864.

PEREIRA, Gaspar Martins (2010), História do Douro e do Vinho do Porto, Vol. 4 - Crise e Reconstrução. O Douro e o Vinho do Porto no Século XIX, Porto, Afrontamento.

PIKETTY, Thomas (2014), "Capital in the Twenty-First Century: A Multidimensional Approach to the History of Capital and Social Classes", The British Journal of Sociology, 65(4), 736-747.

REIS, Jaime (1993), O atraso económico português (1850-1930), Lisboa, Imprensa Nacional-Casa da Moeda.

REIS, Jaime (1996), O Banco de Portugal - das origens a 1914, Vol. 1 - Antecedentes, fundação e consolidação, c. 1821-1857, Lisboa, Banco de Portugal.

REIS, Jaime (2010), "Institutions and Economic Growth in the Atlantic Periphery: The Efficiency of the Portuguese Machinery of Justice, 1870-1910," in Hadi Salehi Esfahani, Giovanni Facchini, Geoffrey J. D. Hewings (eds.), Economic Development in Latin America: Essay in Honor of Werner Baer, London, Palgrave Macmillan, 73-101.

REIS, Jaime (2011), "The Portuguese Judicial System in the Nineteenth Century: Rules, Risks, and Judges", in Debin Ma, Jan Luiten van Zanden (eds.), Law and Long-Term Economic Change: A Eurasian Perspective, Standford, Standford University Press, 277-299.

REIS, Jaime (2011), Uma elite financeira: os corpos sociais do Banco de Portugal, c. 1846-1914, Lisboa, Banco de Portugal.

RICHARDSON, David, SILVA, Filipa Ribeiro da (2015), Networks and Trans-Cultural Exchange. Slave Trading in the South Atlantic, 1590-1867, Leiden, Boston, Brill.

RINGER, Fritz (2002), "Max Weber on Causal Analysis, Interpretation, and Comparison", History and Theory, 41(2), 163-178.

SILVA, Filipa Ribeiro da, CARVALHAL, Hélder (2020), "Reconsidering the Southern European Model: Marital Status, Women's Work and Labour Relations in Mid-Eighteenth-Century Portugal", Revista de Historia Económica / Journal of Iberian and Latin American Economic History, 38(1), 45-77. 
SZOSTAK, Rick (2006), "Economic History as it is and Should Be: Toward an Open, Honest, Methodologically Flexible, Theoretically Diverse, Interdisciplinary Exploration of the Causes and Consequences of Economic Growth", The Journal of Socio-Economics, 35(4), 727-750.

VALÉRIO, Nuno (coord.) (2007-2010), História do sistema bancário português, 2 vols., Lisboa, Banco de Portugal.

WEBER, Max (1978), Economy and Society: An Outline of Interpretive Sociology, Berkeley, Los Angeles, London, University of California Press.

WRIGHT, Claire, VILLE, Simon (2017), "Visualising the Interdisciplinary Research Field: The Life Cycle of Economic History in Australia", Minerva, 55(3), 321-340. 